\title{
INVESTASI DANA ZAKAT SEBELUM DIDISTRIBUSIKAN KEPADA MUSTAHIQ DALAM PERSPEKTIF HUKUM EKONOMI SYARIAH
}

\section{INVESTMENT OF ZAKAT FUNDS BEFORE DISTRIBUTED TO MUSTAHIQ IN PERSPECTIVE OF SHARIA ECONOMIC LAWS}

\author{
Anisa Marseli1a, Zainuddin² \\ 1aProgram Studi Ekonomi Syariah Program Pascasarjana Institut Agama Islam Negeri \\ Batusangkar, Jl. Jendral Sudirman, Lima Kaum, Batusangkar, e-mail: \\ icaanisa29@gmail.com \\ 2Program Studi Ekonomi Syariah Program Pascasarjana Institut Agama Islam Negeri \\ Batusangkar, Jl. Jendral Sudirman, Lima Kaum, Batusangkar, e-mail: \\ zainuddin@iainbatusangkar.ac.id
}

\begin{abstract}
ABSTRAK
Artikel ini mengkaji hukum menginvestasikan dana zakat sebelum dibagikan kepada mustahiq. Masalahnya adalah di satu sisi dana zakat milik mustahiq, di sisi lain amil bertindak hukum di atas milik mustahiq tanpa ada keizinannya. Jenis penelitian ini adalah penelitian kepustakaan. Data dalam penelitian ini dikumpulkan dengan cara membaca literatur yang relevan dengan hukum menginvestasikan dana zakat sebelum dibagikan kepada mustahiq dan dianalisis dengan menggunakan deskriptif kualitatif. Hasil dari penelitian ini adalah hukum menginvestasikan dana zakat oleh amil sebelum didistribusikan kepada mustahiq tidak boleh. Hal ini dikarenakan dana zakat adalah milik penuh mustahik, pihak pengenola hanya sebagai perantara antara muzakki dan mustahik. Di sisi lain, menginvestasikan dana zakat akan menangguhkan pendistribusiannya atau pembagian harta kepada yang berhak menerimanya (muzakki) padahal pembayaran zakat itu sendiri harus fauriyyah.
\end{abstract}

Kata Kunci: Investasi, Dana Zakat, Hukum Ekonomi Syariah

\begin{abstract}
This article examines the law of investing zakat funds before being distributed to mustahiq. The problem is that on the one hand the charity funds mustahiq, on the other hand amil acts in the law above mustahiq's property without his permission. This type of research is a library research. The data in this study were collected by reading literature relevant to the law of investing zakat funds before being distributed to mustahiq and analyzed using descriptive qualitative. The result of this research is that the law of investing zakat funds by amil before distribution to mustahiq is prohibited. This is because zakat funds are fully owned by mustahik, the manager is only an intermediary between muzakki and mustahik. On the other hand, investing zakat funds will delay its distribution or distribution of assets to those who are entitled to receive it (muzakki) even though the zakat payment itself must be fauriyyah.
\end{abstract}

Keywords: Investment, Zakat Fund, Sharia Economic Law 
Marseli, A. dkk. 2020. Investasi Dana Zakat Sebelum Didistribusikan Kepada Mustahiq Dalam Tinjauan Hukum Ekonomi Syariah. Jurnal Syarikah 6 (2): 182-188.

\section{PENDAHULUAN}

Zakat merupakan suatu kewajiban yang harus ditunaikan oleh setiap muslim, karena kewajiban zakat bersifat personal tanpa memandang usia (Bachmid, 2012). Zakat dikeluarkan setahun sekali dengan tujuan untuk membersihkan diri dan harta dari hal-hal yang kurang baik (Umah, 2011). Oleh sebab itu zakat merupakan suatu kewajiban yang ditunaikan umat Islam.

Zakat bertujuan untuk membersihkan harta dan juga memiliki fungsi sosial yang dapat dilihat dari pendistribusi zakat yang mencakup delapan golongan (asnaf samaniyah), yaitu: fakir, miskin, amil, muallaf, riqab, gharim, fi sabilillah dan ibnu sabil Hafiuddhin, 2002). Kedelapan golongan ini secara syara' adalah orang yang berhak menerima zakat (Iska dan Rizal, 2005).

Untuk mencapai pengelolaan dana zakat dapat dilakukan secara efektif maka harta zakat itu dapat diinvestasikan. Zumrotun menyebutkan harta zakat dari beberapa orang dikumpulkan, lalu dimanfaatkan untuk diinvestasikan ke berbagai usaha. Kemudian program investasi juga menjadi pilihan beberapa lembaga zakat agar dana tersebut semakin berkembang (Zumrotun, 2016). Namun saat ini masih terdapat perdebatan mengenai hukum investasi dana zakat sebelum dibagikan ke mustahiq (Nabylaputri, 2017).

Investasi dana zakat merupakan suatu fenomena yang menjadi perhatian para praktisi maupun pemikir zakat kontemporer saat ini. Polemik investasi dana zakat masih terus menjadi perdebatan (Hasan, 2003). Dana zakat merupakan amanah dari muzaki atas perintah Allah SWT untuk didistribuskan kepada pihak-pihak yang telah ditetapkan oleh Allah SWT.Suatu sisi dana zakat sebelum dibagikan kepada mustahiqakan besar manfaatnya jika diinvestasikan. Potensi zakat yang sangat besar akan memberikan manfaat jika diinvestasikan dalam bentuk saham dan obligasi sehingga dapat membantu para mudharib yang membutuhkan dana. Namun, investasi tidak dapat lepas dari risiko kerugian baik dalam bentuk risiko imbal hasil atau risiko fraud. Dari persoAlan tersebut muncul berbagai pertanyaan bagaimana hukum menginvestasikan dana zakat sebelum dibagikan kepada mustahiq berdasarkan hukum ekonomi syariah. Kemudian di satu sisi dana zakat milik mustahiq di sisi lain amil bertindak hukum di atas milik mustahiq tanpa ada keizinannya.

\section{MATERI DAN METODE}

Jenis penelitian ini adalah library research (penelitian kepustakaan). Penelitian library research adalah penelitian yang dilakukan dengan mengumpulkan sumber-sumber data melalui teknik dokumentasi (Sugiyono, 2012). Data dalam penelitian ini dikumpulkan dengan cara membaca literatur yang relevan dengan hukum menginvestasikan dana zakat sebelum dibagikan kepada mustahik. Data diolah kemudian dianalisis dengan cara menggunakan deskriptif kualitatif. 


\section{HASIL DAN PEMBAHASAN}

\section{Investasi Dana Zakat Sebelum Didistribusikan Kepada Mustahiq}

Kegiatan berinvestasi merupakan perkara muamalah yang diperbolehkan dalam Islam sebagaimana kaidah fiqh muamalah (Rizal, 2011). Hukum awal seluruh kegiatan muamalah adalah mubah seperti yang disebutkan dalam الأَصْلُ فِي

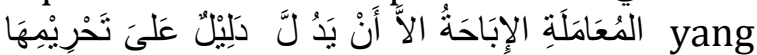
artinya adalah "hukum asal dari muamalah adalah boleh sampai terdapat dalil yang mengharamkannya". Dalam kaidah ini dapat diartikan sebagai hukum asal dari seluruh transaksi muamalah adalah boleh sampai ada dalil yang mengharamkannya (Djazuli, 2006). Investasi dalam Islam merupakan sebuah kontrak kerjasama antara dua pihak yaitu shahibul maal dan mudharib untuk mengelola suatu usaha dan hasilnya akan dibagi sesuai dengan kesepakatan (Rizal, Elfadhili, Wardhani, dan Zainudin, 2018).

Kegiatan investasi tidak terlepas dari berbagai risiko seperti risiko imbal hasil dan risiko fraud. Risiko imbal hasil adalah risiko atas terjadinya pengembalian modal dan hasil yang tidak sesuai dengan ekspektasi (Rusliati dan Farida, 2010). Artinya terdapat kemungkinan pihak shahibul maal akan mengalami kerugian akibat kegagalan usaha dari pihak mudharib.Risiko fraud adalah tindakan illegal atau melakukan kegiatan tidak semestinya yang disengaja dengan tujuan untuk melalui yang lain di mana korban menderita kerugian dan pelaku fraudmemperoleh keuntungan (Tjahyono, dkk, 2013). Artinya terdapat kemungkinan adanya tindak kecurangan yang dilakukan oleh mudharib atas penyelewangan dana yang telah diinvestasikan oleh shahibul maal.

Zakat merupakan hak kedelapan golongan tersebut yang terdapat pada harta orang-orang kaya.Selama salah satu dari delapan golongan itu ada di sekitar kita, maka zakat wajib diserahkan kepadanya. Pendistribusian dana zakat sendiri harus langsung disalurkan kepada 8 asnaf yang sudah dijelaskan di dalam alqur'an, jumlah yang didistribusikannya pun harus utuh tidak boleh berkurang dan tidak boleh mengalami penundaan.Lalu, bagaimanakah hukum menginvestasikan dana zakat? Apakah boleh dana zakat boleh diinvestasikan sebelum dibagikan kepada mustahiq?

Seperti yang kita ketahui, menginvestasikan dana zakat bisa menyebabkan penundaan distribusi dana zakat kepada para mustahiqnya atau bahkan bisa menghalanginya sama sekali bilamana investasi itu mengalami kerugian dan modalnya habis. Oleh sebab itu, para ulama modern memfatwakan tidak boleh menginvestasikan dana zakat. Ulama anggota komisi fatwa juga berpendapat, kalau dana berasal dari zakat maka yang wajib adalah mendistribusikannya. Ulama yang membolehkan memiiki argumen bahwa menginvestasikan dana zakat itu boleh dengan syarat kebutuhan mustahiq sudah terpenuhi.

Penafsiran dari potongan surat atTaubah ayat 60 lil-fuqara'i dan wa almasakini yang mempunyai makna bahwasanya ayat tersebut menjelaskan tentang kepemilikan dari harta zakat tersebut adalah fakir dan miskin dengan adanya kata li. Harta zakat yang diberikan oleh muzakki kepada pihak yang sudah diberi wewenang untuk mengelolanya yaitu BAZNAS merupakan hak milik dari mustahiq yang belum ditunjuk orangnya. Dalam hal ini harta zakat yang dimiliki oleh para mustahiqini tidak dapat digunakan sewenang-wenangnya oleh pihak pengelolanya. Maka dari itu harta zakat wajib diberikan atau didistribusikan kepada mustahiq zakat. Terkait dengan investasi dana zakat, dalam hal ini harta zakat tidak boleh diinvestasikan sebelum dibagikan kepada mustahiq zakat. 
Wahbah Zuhaily, Abdullah Nashih Ulwan, Muhamad Atha' al-Sayyid dan Syekh Taqy Utsmany sebagaimana dikutip oleh Fachruddin(2018) menyatakan keharaman investasi dana zakat, dengan alasan :

1. Investasi dana zakat dalam bentuk apapun tentu akan menangguhkan pendistribusiannya atau pembagian harta kepada yang berhak menerimanya (muzakki) padahal pembayaran zakat itu sendiri harus fauriyyah.

2. Investasi dana zakat dalam bentuk apapaun akan mengancam adanya kerugian atau kerusakan harta karena dalam bisnis ada dua kemungkinan yaitu ada untung dan rugi.

3. Investasi dana zakat dalam bentuk apapun akan menyedot dana operasional lebih banyak dari dana zakat yang terkumpul itu sendiri.

4. Investasi dana zakat dalam bentuk apapun menyebabkan hilangnya kepemilikan harta secara personal karena semua dana hak asnaf berupa kepemilikan kolektif. Ini tentu bertentangan dengan pendapat jumhur fuqaha yang mensyaratkan adanya kepemilikan harta yang sempurna bagi mustahiq saat pembayaran zakat.

5. Peran imam atau yang mewakilinya hanyalah kolektor, bukan manager pengelolaan.

Farishta G. de Zayas dalam bukunya The Law and Institution of Zakat, sebagaimana dikuti oleh Facrudin (2018) mengemukakan tentang beberapa rules governing the administration of zakat, salah satunya pada poin ke 76 menyebutkan bahwa dana zakat tidak dapat diinvestasikan dalam bentuk apa pun terhadap perusahaan bisnis. Larangan ini dibenarkan oleh fakta bahwa investasi harus melibatkan risiko, sementara tidak adanya ketersediaan dana sementara yang dapat segera digunakan. Dengan demikian, investasi dana zakat di perusahaan bisnis akan diragukan, terlebih sangat melanggar prinsip-prinsip Hukum Zakat yang didasarkan bahwa pengumpulan Zakat siap untuk segera digunakan, sesuai dengan perintah dari Al-Quran dan Sunnah Nabi.

MUI mengeluarkan fatwa mengenai investasi dana zakat ini. Dalam fatwa MUI no 4 tahun 2003, menetapkan bahwa:

1. Zakat mal harus dikeluarkan sesegera mungkin (fauriyah), baik dari muzakki kepada amil maupun dari amil kepada mustahiq.

2. Penyaluran (tauzi)distribusi) zakat mal dari amil kepada mustahiq, walaupun pada dasarnya harus fauriyah,dapat di-ta'khir-kan apabila mustahiknya belum ada atau ada kemaslahatan yang lebih besar.

3. Maslahat ditentukan oleh Pemerintah dengan berpegang pada aturan-aturan kemaslahatan (sehingga maslahat tersebut merupakan maslahat syar'iyah.

4. Zakat yang di-ta'khir-kan boleh diinvestasikan (istitsmar) dengan syarat-syarat sebagai berikut :

a. Harus disalurkan pada usaha yang dibenarkan oleh syariah dan peraturan yang berlaku (althuruq al-masyru'ah).

b. Diinvestasikan pada bidangbidang usaha yang diyakini akan memberikan keuntungan atas dasar studi kelayakan.

c. Dibina dan diawasi oleh pihakpihak yang memiliki kompetensi.

d. Dilakukan oleh institusi/lembaga yang professional dan dapat dipercaya (amanah).

e. Izin investasi (istitsmar) harus diperoleh dari Pemerintah dan Pemerintah harus menggantinya apabila terjadi kerugian atau pailit.

f. Tidak ada fakir miskin yang kelaparan atau memerlukan biaya 
yang tidak bisa ditunda pada saat harta zakat itu diinvestasikan.

g. Pembagian zakat yang di-ta'khirkan karena diinvestasikan harus dibatasi waktunya.

Menurut penulis fatwa tersebut dapat dikritisi atau dijelaskan bahwasanya harta zakat harus segerakan dibagikan kepada mustahiq jika ingin menginvestasikan dana tersebut banyak persyaratan yang harus dipenuhi oleh pihak pengelola zakat dengan syarat harus adanya kemaslahatan besar dan tidak ada fakir dan miskin lagi. Tapi pada pada kenyataanya sampai hari ini di Indonesia sendiri belum ada ditemukan tempat yang tidak ada fakir dan miskinnya. Selanjutnya kalaupun MUI membolehkan menginvestasikan dana zakat sebelum dibagikan kepada mustahiq meskipun ada syarat-syarat tertentu yang harus dipenuhi oleh amil namun jika terjadi permasalahan yang berisiko kepada kerugian lantas siapa yang harus menanggung kerugian tersebut?

Di sisi lain para ulama membolehkan zakat untuk diambil manfaatnya ataupun diproduktifkan sebagaimana dalam keputusan Lembaga Pengkajian Fiqh Islam sebagai berikut: Sementara menurut jumhur ulama semisal Yusuf Qaradawi, Abdul Fattah Abu Guddah, Abdul Aziz Khayyath, Abdus Salam Ibady, Muhamad Salih, Mustafa AlZarqa dan Hasan Abdullah alAminsebagaimana dikutip oleh Yantoyang menyatakan hukum menginvestasikan dana zakat adalah halal. Argumen jumhur ini adalah sebagai berikut. Mustafa al-Zarqa mengatakan,"Investasi adalah pengelolaan harta untuk meraih keuntungan. Maka dana zakat bisa diinvestasikan dalam bentuk apapun selama dikelola oleh tangan-tangan profesional" (Yanto, 2015)

Pendapat Yusuf Al-Qardawi (dalam Fauzi, 2012) yang menyatakan bahwa
"Berdasarkan madzhab yang paling sahih, bisa dikatakan bahwa lembaga zakat boleh menginvestasikan dana zakat yang diterima secara melimpah dalam bentuk apapun seperti ruko dan yang sejenisnya. Hasil yang didapat dari investasi tersebut bisa disalurkan kepada para mustahiq secara periodik. Bentuk investasi dana zakat itu tidaklah boleh dijual dan dialihkan kepemilikannya sehingga menjadi bentuk setengah wakaf.

Berdasarkan pendapat ulama tersebut di atas M. Arief Mufraini dalam Akuntansi dan Manajemen Zakat memberikan rekomendasi bagi para amil sebagai upaya mengakomodasi sejumlah pendapat mazhab yang melegalkan investasi dana zakat:

1. Amil dapat menginvestasikan dana zakatnya setelah para mustahiq menerima dana zakat terlebih dahulu. Jadi dalam hal ini amil hanya berlaku sebagai wakil dari keseluruhan mustahiq jika akan menginvestasikan dana zakat dalam bentuk surat berharga.

2. Amil dapat menginvestasikan dana zakatnya setelah mempunyai perhitungan matang pada usaha/ industri yang menjadi objek investasi.

Berdasarkan pernyataan di atas pembagian harta zakat dapat dilakukan dengan dua versi yaitu dana zakat yang dibagikan habis, dengan kata lain dana zakat yang disalurkan kepada mustahiq sudah diberikan secara utuh kepada mustahiq zakat. Selanjutnya versi kedua yaitu pembagian dana zakat dalam bentuk lembar saham, dengan kata lain dana zakat diinvestasikan yang mana amil sebagai mudharib dengan menggunakan akad kesepakatan antara amil dengan mustahiq dengan adanya penandatangan tanda terima lembar saham.

Kemudian dana zakat boleh diinvestasikan setelah zakat dibagikan terlebih dahulu kepada mustahiq. Jika dana zakat sudah diberikan kepada mustahiq terlebih dahulu yang kemudian 
ditarik kembali untuk melakukan investasi, maka pihak amil juga akan kesulitan dalam melakukan penarikan dana tersebut. Disisi lain mustahiq juga tidak akan mudah begitu saja menyerahkan kembali dana tersebut karena mustahiq juga perlu memnuhi kebutuhan hidupnya. Setelah kebutuhan hidupnya tercukupi maka mustahiq baru bersedia menyerahkan dananya kembali. Selanjutnya kalaupun amil dapat menginvestasikan dana zakatnya setelah mempunyai perhitungan matang pada usaha/industri yang menjadi objek investasi jika terjadi kerugian pada suatu saat ini siapa yang akan menanggung kerugian tersebut, sementara ini adalah dana mustahiq.

Dari hal tersebut dapat disimpulkan bahwa menginvestasikan dana zakat sebelum dibagikan kepada mustahiq tidak boleh karena akan terjadi penghambatan dan pengurangan dana (jika rugi). Alasan selanjutnya karena harta zakat bukan milik amil namun hak milik mustahik meskipun mustahiqnya belum ditentukan. Meskipun menurut fatwa MUI menginvestasikan dana zakat dibolehkan asal sudah memenuhi syarat. Namun ada point penting yang nampaknya masih sulit untuk dilaksanakan pada syarat tersebut, yaitu boleh menginvestasikan dana zakat asal tidak ada fakir miskin yang kelaparan atau memerlukan biaya yang tidak bisa ditunda pada saat harta zakat tersebut diinvestasikan. Pada kenyataannya jumlah kemiskinan di Indonesia masih sangat tinggi, bahkan dana zakat yang ada masih belum bisa memenuhi kebutuhan para mustahik. Oleh karena itu menginvestasikan dana zakat tidak boleh.

\section{KESIMPULAN DAN IMPLIKASI}

Berdasarkan pembahasan di atas maka dapat disimpulkan bahwa menginvestasikan dana zakat sebelum dibagikan atau didistribusikan kepada mustahiq hukumnya haram atau tidak boleh. Alasanyanya adalah dana zakat adalah milik penuh mustahik, pihak pengenola hanya sebagai perantara antara muzakki dan mustahik. Selanjutnya adalah menginvestasikan dana zakat akan menangguhkan pendistribusiannya atau pembagian harta kepada yang berhak menerimanya (muzakki) padahal pembayaran zakat itu sendiri harus fauriyyah. Investasi dana zakat dalam bentuk apapun akan mengancam adanya kerugian atau kerusakan harta karena dalam bisnis ada dua kemungkinan yaitu ada untung dan rugi. Investasi dana zakat dalam bentuk apapun akan menyedot dana operasional lebih banyak dari dana zakat yang terkumpul itu sendiri. Investasi dana zakat dalam bentuk apapun menyebabkan hilangnya kepemilikan harta secara personal karena semua dana hak asnaf berupa kepemilikan kolektif. Ini tentu bertentangan dengan pendapat jumhur fuqaha yang mensyaratkan adanya kepemilikan harta yang sempurna bagi mustahiq saat pembayaran zakat.Peran imam atau yang mewakilinya hanyalah kolektor bukan manager pengelolaan.

\section{DAFTAR PUSTAKA}

Bachmid, G. (2012). Perilaku Muzakki Dalam Membayar Zakat Mal (Studi Fenomenologi Pengalaman Muzakki Di Kota Kendari). Jurnal Aplikasi Manajemen, 10(2), 425-436.

Biduan, P. G. (2015). Strategi Pengelolaan Pariwisata Dalam Rangka Peningkatan Pendapatan Asli Daerah Di Dinas Kebudayaan Dan Pariwisata Kabupatenkepulauan Sangihe. Jurnal Eksekutif, 1(7).

Departemen Agama, R. I. (1996). alQur'an al-Karim dan Terjemahnya. Semarang: PT. Karya Toha Putra. 
Didin Hafiduddin (2002) Zakat dalam Perekonomian Modern. Jakarta: Gema Insani Press

Djazuli. (2006). Kaidah-Kaidah Fiqih: Kaidah-Kaidah Hukum Islam dalam MenyelesaikanMasalah-Masalah yang Praktis, Ed.1, cet. 3, Jakarta: Kencana

Fatwa DSN MUI Nomor 04/DSNMUI/IV/2003 tentang Penggunaan Dana Zakat untuk Istismar (Investasi)

Hasan .M. A. (2003), Masail Fiqhiyah (Zakat, Pajak, Ansuransi dan Lembaga Keuangan). Jakarta: PT. Rja Grafindo Persada

Iska, S. Rizal. (2005). Lembaga Keuangan Syari'ah, Batusangkar : IAIN Batusangkar Press

Mufraini. M. A. (2008). Akuntansi dan Manajemen Zakat. Jakarta: Kencana

Nabylaputri, E. Y. (2017). Pandangan Pengurus Lembaga Amil Zakat Infaq Dan Shadaqah Organisasi Masyarakat Islam Terhadap Hukum Investasi Zakat (Doctoral dissertation, Universitas Islam Negeri Maulana Malik Ibrahim).

Nurlita, A. (2015). Investasi di Pasar Modal Syariah dalam Kajian Islam.Kutubkhanah, 17(1), 1-20.

Rizal, S., \& Si, M. (2011). Kontrak Mudharabah, Permasalahan, dan Alternatif Solusi. Jurnal Ekonomi Islam, 3.

Rizal, R., Elfadhli, E., Wardhani, F. S., \& Zainuddin, Z. (2018).Kongsi Pemilikan Rumah Berbasis Syariah Perbandingan Antara Bank Muamalat Indonesia dan Bank Rakyat Indonesia Syariah.Maqdis:
Jurnal Kajian Ekonomi Islam, 3(2), 209-219.

Rizkaul. H. Fachrudin. (2018). Investasi Dana Zakat

Rusliati, E., \& Farida, E. N. (2010).Pemecahan Saham Terhadap Likuiditas dan Return Saham.Jurnal Bisnis dan Akuntansi, 12(3), 161174.

Septiarini, D. F. (2011).Pengaruh Transparansi dan Akuntabilitas Terhadap Pengumpulan Dana Zakat, Infaq dan Shodaqoh pada LAZ di Surabaya.AKRUAL: Jurnal Akuntansi, 2(2), 172-199.

Sugiyono. 2012. Metode Penelitian Bisnis. Bandung : Alfabeta

Taufik Hidayat, S. E., \& Si, M. (2011).Buku Pintar Investasi Syariah.Mediakita.

Tjhajono, Subagio, dkk. 2013. Bussines Crime and Ethics : Konsep dan Studi Kasus Fraud di Indonesia dan Global : Yogyakarta : Andi

Umah, U. K. (2011). Penerapan Akuntansi Zakat Pada Lembaga Amil Zakat (Studi Pada LAZ DPU DT Cabang Semarang). Value Added| Majalah Ekonomi Dan Bisnis, 7(2).

Usman, S. A. (2019). Strategi Pengelola Zakat Dalam Menggulangi Kemiskinan. Dedikasi: Journal of Community Engagment, 2(3), 89104.

Waluya, A. H. (2017). Fikih Zakat Simpanan Di Bank Dan HukumHukumnya. al-Uqud: Journal of Islamic Economics, 1(2), 156-182.

Zumrotun, S. (2016). Peluang, Tantangan, dan Stategi Zakat dalam Pemberdayaan Ekonomi Umat. AHKAM: Jurnal Ilmu Syariah, 16(1) 